\title{
해용 SOVEREIGNTY IN ISLAM - A REFLECTION OF TRADITION AND CONTEMPORARINESS IN MODERN POLITICAL SYSTEMS
}

\author{
Andrijana Maksimović \\ State University of Novi Pazar \\ Zoran Milosavljević \\ Institute for Political Studies, Belgrade
}

Sovereignty in Islam means hakemia in Arabic and it is related to a

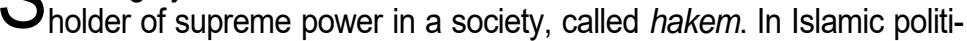
cal and legal theory, a holder of sovereignty is God. God is a holder of supreme power, and above all, a legislator. Thus, in Islamic countries, a secular concept of a state regulation and having nation as a holder of sovereignty, man's rights and freedom of political organization is unacceptable. Moreover, when there is such a regulation in legal and political acts, it contains the previous fact that the sovereignty holder is God, and a nation's sovereignty is limited. Despite numerous changes that have happened in Islamic world during history, this view and understanding of sovereignty has not changed. Until recently, Islamic countries have not had any laws except those regulated by religious authorities. Even when the leaders used their power to proclaim regulations of a laic character, they had to give religious legitimacy to those regulations, and God has been and still is the only holder of sovereignty. Having showed how traditional Islam has treated sovereignty, the aim of the authors is to show how it is treated today. In fact, the autors' intention is to examine whether the idea of God's sovereignty is still present. As previously said, in essence, nothing has changed. Or more precisely, the theory on God as an exclusive sovereignty holder has not changed in almost the entire Islamic world. However, something else has been done, and it is contained in the fact that this view has been wrapped in contemporariness. The paper analyses the issue of sovereignty in Islam through two approaches: the first approach represents a thesis on unity of religion and politics in Islam, while the second one deals with the analyses of political praxis of Islamic states. On the basis of the analyses of Constitutional texts and practice, it is possible to divide Islamic states into three groups. The first group is the one where, by the Constitution, is clearly determined that God is a sovereignty holder; the second one, where a nation or a state has been determined as sovereignty, either as independent holders of sovereignty or in a community with its leader. The third group of states is the one that determines its sovereignty and holder in a similar way as it has been done in Europe and America. According to the Constitutional provision of these states on Islam as a state religion, conclusions on sovereignty of nations and borders have been drawn.

Key Words: Islam, sovereignty, God, Constitution 
"This religion (Islam) is a serious, dynamic and practical way of life (man haj). It has come with its aim to arrange life in its practical form and to subdue a concrete reality of a man to its

own criteria: to approve it, correct it or change from its roots. Therefore, its regulations are related to only real situations in a society that from the very beginning acknowledges only one power, the power of God" (Kulenović, 2008, stated to: Kutb,1996: 30)

$\mathrm{T}^{\mathrm{h}}$ he primary question this paper should start with is why during studying the influence of religion on the entire social relations the influence of Islam is treated more importantly than the influence of other religions. The answer to this question is contained in the fact that in a number of countries of other traditions, there has been secularization of religion, and religion has been put into a private sphere of an individual. In difference to this, in a great part of Islamic world, Islam has been determined as a state religion by its Constitutional norm or as a primary law source. In Islamic nation languages, there is no difference between sacred or world or time order. Even in a translation case, it is not possible to find appropriate terms (Nasr, 1967).

The universality of Islam has been reflected in the fact that this is not a religion in a traditional sense directed towards a community, but rather the life philosophy. Thus, it differs from other religions and non-religious ideologies. Religion (dyne) for Islam means a complete concept: theory, ideology, philosophy, law, and a way and life system. It is usual to underline three different meanings of the word dyne: a) judgment, reward, b) a custom, habit and c) religion, faith. Dyne thus includes: obligation, obedience, reward. Regardless of its origin, there is an idea on a debt to be paid (therefore obligation), and a way that has been directed or to be followed in a complete heart obedience. Dyne means obligations equal with judgment, and when taken as a debt to be paid, dyne must be translated with faith, having the most common meaning (Smailagić, 1990). This is the system of the entire life and thus Islam seeks complete devotion from a man to God. It rejects division of people into religious and world ones. In that sense, pursuant to Islamic teaching, as we can see, there is no division of the world by religion, since in essence, everything is religion, and has the smell of God (Nasr, 1982). All of these have to serve Islam. If we reconsider technical and institutional resources of traditional Islamic societies, we can notice they assume literacy, urban life, long-distance trade and a central power (Gellner, 2000). The central power did not possess adequate technical and organizational resources for efficient submission of tribes.

In Islam the situation is completely different from European-American context, where law has been shown as a product of political struggle in the Parliament. Law is the most typical manifestation of religious teaching in Islam. Actually, the concept of law itself, as a system of norms being sanctioned by a state, is unknown in Islamic teaching. Islamic law is a result of putting effort into the Quran and Sunnet and derivation of practical regulations from the ones. Sheriah is a God's proclamation and fikh ${ }^{1}$ is human work. It is necessary to allow the complete Islamic right, so as Islam would be practiced in its complete

\footnotetext{
${ }^{1}$ Fikh is a word that has meant understanding, knowledge and realization in the beginning and it has been applied to all branches of knowledge. It has also become a professional term that serves for determination of law sciences, the science of religious law on Islam. In its broadest sense, this word covers all forms of religious, political and private life (Smailagić, 1990).
} 
sense. It is not possible to enforce law without a state, and it forces citizens, by means of force, to respect religious dispositions and to apply sanctions if they have been violated. Thus, if law is a functional expression of Islam, then it is clear that we need a state for it, since there is no law without a state. And this means there is no Islam without an Islamic state (Jevtić, 2008). The state power is the only one to secure the application of regulations. Here, we can find the essence of relation of Islam and a state. Religion serves a state to accomplish its aim, and thus, by its nature, it is religious and all its actions are religious ones. In Islam, politics is inseparable from religion, and in that sense, accomplishment of Islam is accomplishment of Islamic politics and Islamic state.

From all previously stated, it can be noticed that in the states with Islamic population, religion has been built into the foundations of a political system. Therefore, Islam has survived throughout history as a primary source of ideology and legitimacy all has been called upon (Jevtić, 1989). Pursuant to Islamic teaching, a secular concept of a state regulation is unacceptable, as well as a nation as a holder of sovereignty, rights of a man, freedoms of political organization and everything else derived from this concept.

In this paper, we shall present how sovereignty has been understood by this great world religion. After presentation of how traditional Islam has treated sovereignty and its holders, the authors' intention is to show how it is treated today.

\section{The Principles of Early Islamic Politics}

Sovereignty has been determined as a factual characteristic of the state power that consists of its legal limitlessness, i.e. non-existence of legal means for its limitation (Lukić, 1960). Sovereignty in Islam has been determined by the term hakemia and it is related to the holder of supreme power in a society called hakem.

Among Islamic political philosophers, there is an agreement that the only sovereignty holder is Allah and all power belongs only to Him. The very word Islam means obedience to God, and a Muslim is the one who obeys Him. Thus, the only legislator is God, and leaders are His representatives on Earth, and they are limited in their actions by the Sheriah. Since sovereignty only belongs to God, his law has been sent (Sheriah) to govern, and thus, the authority is the law itself. God directly governs a state by the laws that have been proclaimed to people in the Quran (Jevtić, 2002).

The obedience to the proclaimed law and disclaimer of own freedom in replacement for it has been called Islam in the Quran (Mevdudi, 1982). The Quran indeed proclaims freedom of a man to decide on issues where Allah and His Prophet have already decided upon. And the one who does not obey Allah and His Prophet is the one that has turned from the right path (Koran, Ayet 36). The Muslim society, established by the arrival of Islam and the state it has formed by overtaking political power, has been founded upon clear principles. The most significant among themare the following:

- Sovereignty belongs to God and an Islamic state is a governorship, where no one has the right to power, and everyone has to be obedient to the Law and live pursuant to the Law,

- All Muslims in a state have equal rights regardless of race, color or language. No individual, a group or nation has special privileges, since these differences could determine a position of someone as a lower one, 
- The Sheriah is the highest Law and everyone must obey it, from the lowest one to a leader of a state,

- The government, its power and goods are entrusted to God to keep them and Muslims should be afraid of God, merciful and justified; no one has the right to use them, to punish them or to be disobedient to the Sheriah,

- A leader of a state shall be appointed based on mutual consultations of Muslims and their agreement. The one shall organize administration and overtake legislative work within the limits provided by the Sheriah,

- The Caliph or Amir should be obedient to everything being righteous and correct, and no one has the right to determine obedience serving to sin and

- The main task of the Caliph or Amir and his government is introduction of Islam and assistance to good, and prevention of evil (Šarif, 1990).

The power of previous Caliphs has been based on the stated principles. Each member of a community has been brought up under the care of the Prophet, and He has known what type of power is suitable to the one's needs. Although the Prophet has not solved the issue of His heir, the members of the community have no doubts that Islam demands a democratic solution of the issue. Therefore, no one had the right to establish hereditary power, use force to conquer it or to appoint the one to be the Caliph. On the contrary, people have chosen four persons where only one should overtake leadership by free will. The first four Caliphs have not performed their administrative or legal duties without consulting the Community of Wisemen. Thus, the ones who advised them had the right to express their opinion freely, with no fear.

The righteous Caliphs have not thought of themselves to be above the law. They claimed they have been equal to any other citizen. They appointed judges, and a judge once being appointed could have a trial against them, like against anyone else. The characteristic of the early Islam is that everyone had equal and righteous treatment pursuant to the principles of the Islamic spirit, since a society has been free of all types of tribal, racial or parochial prejudices. The period of the righteous Caliphate has been described as a bright tower, where all scholars and religious people of later centuries have been viewed as a symbol of religious, moral, political and social system of Islam of par excellence.

The entire political philosophy of the Quran is based on its fundamental understanding of the universe and one should have this in mind when understanding and correctly evaluating the Koran. Based on this concept of the universe, the Quran emphasizes that a real sovereign of people is the one who is the sovereign of the entire universe. Only His power is legal in human actions and other works of creation. Sovereignty of God has been determined in physical sphere of the universe, regardless of whether the obedience is voluntary or not. In this area of one's life, even a man has no choice to act differently. However, in a willing life sphere, a man has been given a certain amount of free will and God does not force the one into blind belief. The Quran says that obedience with no objections belongs only to God. His law has the highest power, and obedience to others or fulfilling someone's will against God's law is not the righteous path. Thus, the Quran says that Prophets are the only source of our knowledge of God's law. They are persons chosen by God to interpret the meaning of these proclamations.

The real form of power for people, pursuant to the Koran, is the one where a state gives its sovereignty to God, and then after admitting legal supremacy of God and His 
Prophet, accepts the position of the Caliphate under the righteous rule of a supreme leader. The powers of the true Caliphate have not been given to any individual, race or community, but to those who believe in God. In this aspect, Islamic Caliphate is different from any kingdom, oligarchy or theocracy. It is even different from modern democracy. There is a fundamental difference between the two. Democracy was born from the seed of a nation's sovereignty, while in Islamic Caliphate, people themselves give their independence to God's sovereignty, and they voluntarily limit their powers, and the promise on governorship shall be given only if they are morally good. The reign of a state is based on understanding that absolute obedience cannot be asked from a nation. This one is obliged to obey until it uses its powers pursuant to God's law proclaimed in the Holy Book. Islamic power represents the reign of divine law above people, and as it has been emphasized by Ernest Gellner, Muslim societies are resistant to secularization from the very reason (Hantington, 2000).

Islamic presentation of religion and politics is based on reading or interpreting the Koran, Muhammad practice and early Islamic community, together with Islamic teaching that spiritual belief and action are two sides of the same medal. Therefore, pursuant to the words of Espozito, Muslims believe that their basic act of belief is the struggle to interweave God's will with their private and public life. Being a Muslim meant not only belonging to a religious community, but to an Islamic state, where Islamic laws have been applied, at least in theory, and not always in practice (Espozito, 2003). When presenting an ideal Islamic state, the purpose of a political authority is to implement divine message into all life spheres. Thus, an ideal Islamic state is the community governed by God's law, instead of theocracy or autocracy that gives power to a priest or leader.

\section{A Reflection of Sovereignty in Contemporary Political Systems}

In almost entire Islamic world, the theory on God as an exclusive holder of sovereignty has not been changed, and it should be said that this teaching is wrapped in contemporariness. The decrease of Caliphate's power in $19^{\text {th }}$ century and its final end at the end of $20^{\text {th }}$ century, has been interpreted as a negative theophany or as "God's anger" towards the Muslims for leaving the righteous path. This explains Islamic revivalism in $20^{\text {th }}$ century and its deep power in certain societies. Religion entering politics happens after certain events that have been catalysts for all of this (Espozito, 2000). Pursuant to the words of Abdullah Omer Nasif: "Islam, in essence, represents a unity of religion and a state. This is the first and most significant one. All previous social-historical systems that Islam has developed in its lap have failed when the Caliphate failed too, when a unique Islamic state has failed. The first duty and a task of modern Ulema are to regain and rebuild these Islamic social institutions and systems among Muslims. And these systems, the experiences and understanding are useful for non-Muslims, either. The current social systems being ruled in the world have not been established pursuant to God's law" (Preporod, 1991).

A number of Islamic states were a consistent part of colonial empires. New states that accepted Islam as a primary source of ideology and legitimacy were formed by the process of decolonization in traditional Islamic areas (Jevtić, 2009). This meant an obli- 
gation to adopt Islamic law and political theories. Together with this process, the efforts of colonial leaders in these areas, brought the mixture of tradition and contemporariness, and this resulted in the creation of political systems that reflected this fact. The elements of tradition are in the fact that Islam is the frame how this new system shall be built, while contemporariness is reflected in the condition to give up the traditional way that had not used any other legislation except a religious one. This is best seen in the fact that Islamic states did not have Constitutions before, and almost all of them have it today. The only exception in this sense is Saudi Arabia that does not have Constitution, i.e. as it has been stated by its representatives, and there is no need to have an act like this, since they already possess it and it is the Koran.

Having all of this in mind, it is particularly interesting to define the term of sovereignty in these states. On the basis of the analyses of Constitutional texts and practice, there is a possibility to divide Islamic states into three groups. The first group of states is the one where it has been clearly defined that God is the holder of sovereign power by the Constitution. The second one, where the governor is a nation or a state, either as independent holders of sovereignty or in a community with a leader, the nation can exercise its rights pursuant to the laws that have been given by the only real holder of sovereignty God. And the third group of states is the one where sovereignty and its holder have been determined in a similar way as it has been done in Europe and America. According to the Constitutional provision of these states on Islam as a state religion, it can be concluded that sovereignty of nations and boundaries are within its framework.

The first group of states that determine God as the sovereignty holder included Libya until the revolution led by Gaddafi, Iran after having Ayatollah Khomeini for its leader, Afghanistan in the period of Taliban reign and Pakistan. In Libya, pursuant to its Constitution from 1951, there has been an emphasis on the fact that sovereignty belongs to God and according to the will of the Mighty one the sovereignty is entrusted to a nation, and the nation entrusts it to a king, again. However, by accepting to be obedient to God, a nation becomes aware that a demand of time must be responded to, and it must be given a new, modern form. Still, by the Constitution, it has been clearly determined that no new law shall be opposite to God, and it is clear that people of Liberia experienced God as a real sovereign. The situation is similar in Pakistan. The very idea of Pakistani state has been conducted since realization of Muslim ideologists that it is impossible in the unique India to accomplish the idea of God's sovereignty. In the period of Taliban reign in Afghanistan, the ruling laws stipulated absolute sovereignty of God.

Besides these two groups of states, there is a very interesting case of Iran. Complete supremacy of Islam has been proclaimed in it over public life, and as a democratic society, it allows regular voting. The Islamic state that was formed in Iran after 1979 was based on the concept of reign of an Islamic lawyer (velayat-e-fagih). The Imam Khomeini undoubtedly rejected monarchy as a form of governing, since he considered it unrelated to the principles of Shiites Islam. The institution of velayat-e-fagih must have been chosenin order not to have negation of Marja'iat Doctrine (Potežica, 2006). Pursuant to this Doctrine, believers follow rules, instructions and decisions brought by Islamic scholars with deep knowledge of Islam and the highest moral virtues in everyday life. Everything else from religious-political teaching of Khomeini was difficult to translate into Constitutional and institutional categories and terms. 
At referendum held on $30^{\text {th }}$ and $31^{\text {st }}$ March 1979 , the nation voted against monarchy and for the creation of Islamic Republic. After it, an election for the Parliament of Experts started, whose task was to adjust the final version of the Constitution. Since there were $73 \mathrm{MPs}, 55$ representatives were of Shiites clergy, for the first time, the Islamic Ulema in Iran directly participated in performing power and was able to create history independently, free of the influence of secular structures.

Therefore, it can be concluded that in these states God has been determined as the sovereignty holder, and this reminds of traditional Islamic teaching. However, there is a significant difference compared to traditional teaching in the fact that the Constitution has been made and numerous laws have been adopted by the National Parliament. Thus, these states leave traditional forms of legislation based on religious authority and adopt Constitution as the highest legal act. Still, this has not meant the complete acceptance of the European concept of sovereignty.

The second group of states, pursuant to determination that the sovereignty holder is a nation, alone or in a community with another leader, the laws where the only real sovereignty holder is God entail Afghanistan, Iraq, Kuwait, Syria, Yemen, Jordan, Malaysia, Morocco and others. Indeed, understanding of sovereignty, i.e. its holder has been determined in this group in a way to be adapted to the spirit of time, and the power of Islam has been so great that in the very constitutions there have been limitations, and they disabled accomplishment of the supreme power of a nation. This clearly emphasizes that sovereignty of a nation is limited and in the places where there are strong Islamic norms, there cannot be regulations to be brought opposite to the ones. Thus, the Constitution of Iraq from 1965 (Jevtić, 2009), stipulates that the Parliament has legislative power, and at the second place of the Constitution, it is said that Islam is a state religion and the very base of the Constitution. From this group of states, the case of Malaysia is particularly interesting. In the Article 11 of the Malaysian Constitution, it has been stated that each person has the right to proclaim their religion, to practice and promote it, and in the Article 4 of the stated Constitution, it has been emphasized that the state law can control promotion of any religion among the members of Islamic religion. If we have in mind the percentage of population in Malaysia that consists of Chinese and Hindi people, then this fact is more than significant. It is more than clear that Islamic proselytism among nonMuslims has been allowed.

It seems that the term sovereignty in the second group is closer to the term of sovereignty in Europe and America, but having a detailed reconsideration, it can be seen that a relation of nation and sovereignty is practically levelled as within the first group of states. Furthermore, what is more interesting, numerous solutions related to the first group of states are more appropriate to the current flows than the characteristics related to the second group of states.

Finally, the third group of states involves Egypt, Tunisia, Algeria and Mauritania. This group of states is characteristic for proclaiming a nation for the sovereignty holder. From this determined sovereignty, it can be said that traditional Islamic teaching on God as the sovereignty holder has disappeared. If we conduct more detailed analyses of this issue, we shall see that if these states have adapted to the modern world, they could not escape from the traditional Islamic Doctrine. This is especially visible through the Constitutional provisions on Islam as a state religion. Thus, it can be said that the idea of God's 
sovereignty is still alive. However, what seems as the necessity is an attempt to reconstruct understanding of inter-national relations in the early period of Islam, reform methodology, replace the old legalistic approach by a political one and secure the respect of the basic principles of Islamic law in this new process of the creation of foreign politics of the Muslim states (Glasnik Rijaseta, 1990). Most states have kept an Islamic mask, and kept recalling to Islam in their Constitutions, for instance that a leader must be a Muslim, or the Sheriah is one of the sources of the law. A deeper presentation of modernization of Islam has been drawn from the process that started in betrayed expectations of Muslims and their disappointment with the ideology fallacy of $20^{\text {th }}$ century. Religious masses have seen their way out in Imams preaching. The consequence of this is the revitalization of Islam in Muslim politics, and this represents a thrown glove to the face of those who believed that religion should be in the very edge of public life, not in its center (Alibašić, 2004). It should be said that there is more honest Islamization in already formed national states. What is a paradox in Islamic world is that Islamists are trying to conquer power in a democratic way. This represents a way of their liberalization from those who opposed progress. Islamism is now put as a propitiator of a state vision and its development, and the ways the very society sees itself and its aims (Espozito, 2002).

\section{Conclusion}

All human beings and cultures that have been developed have the same needs, customs, impulses and wishes that organized as persons determine their way towards their own and social aims. Since human nature is the same, the primary law of cultural development and failure remains always the same. However, since different circumstances, different cultural groups have been developed differently in all parts of the world, and thousands of years of their experience give them their own social and psychological character, and their character creates all differences in their life as the answer to the influence of these circumstances. The Islamic society forms a unique cultural group. It has been obedient to the same laws of growth and failure as in any other cultural group, and it has also developed its own specific characteristics. Therefore, anyone who wants to understand a political system of this part of the planet, must have in mind the role of Islam as the integral ideology in accomplishing sovereignty, since otherwise, the one has no chance to understand true essence of events in this part of the world. There is always a possibility to accomplish something positive in the area of activities that are truly pursuant to traditional principles, under the condition to reveal and accept the truth, above all.

Special attention has been paid not to destroy teaching on God as the only legislator. In the meantime the Caliphs as supreme interpreters of the Sheriah have given their representatives to interpret and apply the Islamic laws. Thus, a theoretical concept of God as sovereign has stayed undestroyed, and in practice, it has been moved more towards their earthly representatives. More recent history has put challenges to Islamic concept of sovereignty. During its struggle to be freed from colonial power, there has been a break of modernistic ideas, which resulted in the acceptance of the European models by the Islamic states. 
It is obvious that the Islamic world and political organization of this part of the planet is very specific, and if we want a fair understanding of events in these areas, we need detailed analyses of the ones. In that sense, the paper has been constructed as a concrete step towards filling a gap in our political and law science, the ones that primarily deal with the term of sovereignty. Thus, there is a tendency that dominates in this part of the world and it does not go towards balancing differences of the sovereignty term, on the contrary, towards making a deeper gap and differences.

\section{Literature}

[1] Alibašić, A. (2004). Političke prilike u muslimanskim zemljama. Sarjevo: Atlas islamskog sveta.

[2] Gellner, E. (2000). Muslim Society. Cambridge: Cambridge University Press.

[3] Glasnik (1990). Rijaset IZ SFRJ, br. 6/1990.

[4] John L. E. (2000). Political Islam and West. JFQ. Spring.

[5] Espozito, L. J. (2002). Oksfordska istorija islama. Beograd.

[6] Espozito, L. J. (2003). Što bi svako trebao znati o islamu. Zagreb.

[7] Jevtić, M. (1989). Islam kao izvor ideologije u legitimitetima u savremenim političkim sistemima. Arhiv za pravne i društvene nauke. br. 4/1989.

[8] Jevtić, M. (2002). Religija i politika, Uvod u politikologiju religije. Beograd: Institut za političke studije.

[9] Jevtić, M. (2008). Ideja islamske transformacije sveta. Politička revija, br. 4/2008.

[10] Jevtić, M. (2009). Politikologija religije. Beograd: Centar za proučavanje religije i versku toleranciju.

[11] Jevtić, M. (2009). Politikologija religije. Beograd.

[12] Kulenović, T. (2008). Politički islam: Osnovni pojmovi, autori i skupine jednog modernog političkog pokreta. Sarajevo.

[13] Lukić, R. (1960). Teorija države i prava. Beograd: Naučna knjiga.

[14] Mevdudi (1982). Zakonodavstvo i idžtihad u islamu. GVIS br. 2/1982.

[15] Potežica, O. (2006). Islamska Republika Imama Homeinija. Beograd: Filip Višnjić.

[16] Preporod (1991). Novi Pazar.

[17] Prijevod Kur' ana. (2005). Novi Pazar.

[18] S.H., N. (1967). Religion and secularism, their meaning and manifestation in Islamic history: Islamic studies. Beirut.

[19] Sejid, H. N. (1982). Religija i sekularizam-njihovo značenje i manifestovanje u muslimanskoj istoriji. GVIS br. 5/1982

[20] Smailagić, N. (1990). Leksikon islama. Sarajevo: Svjetlost.

[21] Hantington, S. (2000). Sukob civilizacija. Podgorica: CID

[22] Šarif, M. (1990). Hitorija islamske filozofije s kratkim pregledom drugih disciplina $i$ savremene renesanse $\mathrm{u}$ islamskim zemljama I i II. Zagreb. 